\title{
The Novelty of Bohuslav Balbín's Biographies about Saint John of Nepomuk and their Role in Proving His Veneration
}

\author{
Tímea Kis N. \\ University of Tokaj, Department of Cultural Heritage Studies, 3950 Sárospatak, Eötvös út 7. \\ Hungary; kis.timea@unithe.hu
}

Received 22 April 2021 | 28 November 2021 Accepted | Published online 20 December 2021

\begin{abstract}
I focus on the attributes of three biographies written about Saint John of Nepomuk by Bohuslav Balbín (1621-1688), a Czech Jesuit monk and historian. I attempt to explain how the features of the ecclesiastic discipline of the cult of saints after the council of Trient and the issue of public respect before canonization can be identified in these texts.

The biographies of Saint John of Nepomuk were written to be more than simple hagiographies. Due to their complexity and structural features, they became materials suitable for challenging Pope Urban VIII's Coelestis Hierusalem decree, in which he firmly forbade the veneration of individuals not approved by the Holy See. Balbín wanted to prove that veneration for Saint John of Nepomuk had existed continuously since his death, and the manifestations of this had characterized contemporary communities as well. Also, that this devotion had become ever more intensive, thus was not inconsistent with Pope Urban VIII's restrictions.
\end{abstract}

Keywords: Saint John of Nepomuk, Bohuslav Balbín, Pope Urban VIII, cult of saints

I focus on the attributes of three biographies written about Saint John of Nepomuk by Bohuslav Balbín (1621-1688), a Czech Jesuit monk and historian. I attempt to explain how the features of the ecclesiastic discipline of the cult of saints after the council of Trient and the issue of public respect before canonization can be identified in these texts. ${ }^{1}$ Saint John of Nepomuk died in 1393, while the cult associated with him remained only local for a long time, but from the second half of the seventeenth century onwards intensively spread and became universally significant throughout Europe. However, as the church did not confirm this public cult until

1 This study is based on my thesis which was defended in 2020: N. Kis, "Kiben Isten abban az üdöben.” 
the first third of the eighteenth century (the beatification of the martyr occurred in 1721, and he was canonized in 1729), Balbín tried to prove with different arguments the martyr's deservingness of respect in his biographies, while polemizing with the Holy See's writings.

Taking into account the changing function and features of the veneration of the saints of the early modern period has a significant and rich tradition in the international academic discourse. ${ }^{2}$

Peter Burke asked the fundamental question whether saints are role models of the age in which they live, or the age in which they were canonized in a book called The Historical Anthropology of Early Modern Italy. ${ }^{3}$ Although the life and work of saints is obviously a reflection of the age in which they were active, today there is consensus about the fact that beginning a canonization process and closing it with a positive result is as much indicated by the contemporary power relations of the church and the secular, political world as the spiritual demand for recognizing saintliness officially. Every canonization transmits such information through which we can glimpse the features of the canonization procedure. The same statement is true irrespective of the happenstance of the canonization: the veneration of saints recognized by the church has not always come about due to the manifestation of a cult-tradition of the community, but making the event official has inevitably been attended by an increase in the cult of the saint.

The council of Trient had the most significant effect on the ideological changes related to the veneration of saints in the early modern period: this was when they redefined the idea of the saint and their representation. ${ }^{4}$ The council tried to frame and integrate the individual and communal manifestations of the cult of saints with a decision accepted at the twenty-fourth sitting of the council on 3 December 1563. They emphasized that it is good and useful to pray to saints, and that their relics and pictures can be respected, but only God can be worshipped. Saints were defined as mediators who create a living connection between God and believers, so respect

2 Burke, "How to be a Counter-Reformation saint," 48-62, and 130-142; Eire, War against the Idols; Ditchfield, "How Not to Be"; Hecht, Katholische Bildertheologie im Zeitalter, 356-64; Sallmann, Naples et ses Saints; Gregory, Salvation at Stake; Suire, La sainteté française; Vidal, "Miracles, Science, and Testimony," 481-508; Dufflin, Medical Miracles; Ditchfield, "Thinking with Saints"; Leone, Saints and Signs; Worchester, "Saints as Cultural History"; Copeland, "Saints, Devotions and Canonisation"; Johns, "Sanctity and social utility"; Sidler, Heiligkeit aushandeln. Cult of saints in Bohemia in the early modern period: Kapner, Barocker Heiligenkult; Shore, The Eagle and the Cross; Shore, Die Landespatrone der böhmischen Länder; Louthan, Converting Bohemia; Louthan, "Tongues, Toes and Bones"; Kubin, "Der Kult des seligen Hroznata."

3 Burke, "How to be a Counter-Reformation saint," 52.

4 Waterworth, The Council of Trent; Denzinger andHünermann, Hitvallások és az Egyház; Denzinger and Hünermann, Das Trienter. 
given to them trends to God. ${ }^{5}$ In line with this, with regard to the aspect of the trustworthiness of saint biographies, taking a critical perspective became more and more important. This demand is evident in the early critiques of the stories of saints from the Legenda Aurea such as those by the humanist Juan Luis Vives (1492-1540), but the new trend can also be identified in the work of early hagiographers after Trient, such as work by the German Lorenz Sauer (1522-1578), the Spanish Pedro de Ribadeneira (1527-1611), and the Spanish Alonso de Villegas (1533-1603).

The claim for rationality that emerged before the Reformation gained more and more ground; it became a basic principal of Catholic demands for renewal aimed at reconciling the results of new academic research with the rhetoric represented by the Catholic church. ${ }^{6}$ This was the most important inspiration for Bollandist and Maurist hagiographic efforts, which made their blissful effects felt in numerous institutions of the church. The most well-known result of these proposals was the renewal of the basic model of hagiographic research involving the strict basic principles of source critique, while the activities of the former established the numerous basic methodological criteria for the increasingly elaborate procedure of canonization. Heribert Rosweyde (1569-1629), a Jesuit priest, then after his death, Jean Bolland (1596-1665), and also his co-workers (and fellows of the order) such as Gottfried Henschen (1601-1681) and Daniel van Papenbroeck (1628-1714), finally and fundamentally renewed the content and formal structure of saint biographies when they published the Acta Sanctorum volumes-collected manuscripts and critical studies of saints that follow the chronological order of saint calendars, but content-wise exceed them, with which they gave a solid response to the critical demands for hagiographic research.

In parallel with the need for critically demanding saint biographies, respect for the deceased as a criterion of saintliness and the changing of the procedure of canonization were keystones of Catholic renewal. ${ }^{7}$ In accordance with the regulations of the council of Trient, and with the claim for centralization by Pope Sixtus V (1585-1590), on 22 January 1588 the Ritual and Ceremonial Congregation (Sacra Congregazione dei Riti e delle Ceremonie) was founded by his Immensa aeterni Dei bull, in which he commanded that a professional committee should examine the biographies and saintliness of those persons who await canonization, and should oversee the related ceremonies as well. The composition of a trustworthy biography

5 Decree of this conclusion: De invocatione, veneratione et reliquiis sanctorum, et sacris imaginibus. vid. Leone, Saints and Signs, 3-8.

6 Eire, War against the Idols, 8-53; Hippolyte Delahaye, The Work of the Bollandists; René Aigrain, L'hagiographie; Leone, Saints and Signs, 21.

7 Veraja, La Beatificazione; Sieger, Die Heiligsprechung; Samerski, "Wie im Himmel”; Ditchfield, “Tridentine Worship," 201-24. 
(Vita) became a requirement of the initiation ceremony, as did the collection and appreciative analysis of miracles connected to the person (Liber miraculum). ${ }^{8}$

The oratorian hagiographer and consultor to the Holy See's Congregazione de Beati, Antonio Gallonio (1556-1605), on the basis of the example of his order founder, Saint Philip Neri, in 1596 called for those who expired in saintliness to be called saints, and for their acts to be recorded in printed form, and for holy mass to be held on the date of their death. He sought to limit public honors through the indicated narrowing down of the occasions of holy masses, and by simplifying the decorative forms of the graves of those who had died who were known for saintliness: according to Gallonio, in the latter case only lanterns could be used-not pictures, nor candles. ${ }^{9}$ Pope Clement VIII (1592-1605) had a contradictory opinion, and in 1602 ordered an investigation due to the mass cult demonstrations at the graves of Saint Ignatius of Loyola and Saint Philip Neri in Rome, and of Saint Charles Borromeo in Milan. In Chiesa Nuova in Rome, for example, in honor of Saint Philip Neri, an altar was dedicated to him even before his canonization, while his grave was decorated, and his picture was placed outside the church and was ornamented with candles and votive items: as the pope noted with sarcasm, if the founder of the oratorian order had been canonized, he would not have had a greater cult than without it. ${ }^{10}$

Pope Urban VIII (1623-1644) undertook to deal with these anomalies, and on 5 July 1634 published his decree Coelestis Hierusalem, in which he firmly forbade the religious cult of individuals not approved by the Holy See, and also stated that the canonization process could begin no earlier than the fiftieth anniversary of the person's death (Saint Charles Borromeo, for example, was canonized 26 years after his death, in 1610). ${ }^{11}$ Lacking this, any form of the public appearance of a cult was limited or prohibited: individuals were not allowed to be called saints or blessed, nor could churches or altars be dedicated to them; holy masses could not be offered to them; and pictures of them could not be hung in churches or public places. Without the permission of the competent bishop according to the territory, their graves were not allowed to be decorated with votive items or candles-permission had to be asked from the Vatican. Finally, he also prohibited portraying them with symbols of saintliness like the nimbus, while details of their so-called miracles and revelations could not be printed and published. ${ }^{12}$

8 Tusor, A barokk pápaság, 148-54, particularly: 153.

9 Ditchfield, Tridentine Worship, 210-11; Sidler, Heiligkeit aushandeln, 53.

10 Cited by: Prospero Lambertini, De servorum Dei II/1, 155. As cited by: Sidler, Heiligkeit aushandeln, 53-4.

11 Burke, "How to be a Counter-Reformation saint," 50. Tusor, “A magyar egyház," 35-66., particularly: 33.

12 Sidler, Heiligkeit aushandeln, 53-4. Tusor, Barokk pápaság, 148-54.; Kubin, Kult des seeligen Hroznata, 35-58, particulary: 42-3. 
Although in a somewhat ambivalent way, the legitimation before canonization of the cult of John of Nepomuk was secured by this papal severity, as in Coelestis Hierusalem it is also stated that those individuals are subject to different judgement whose cult has existed beyond memory (confirmatio cultus ab immemorabili tempore praesisti). ${ }^{13}$ This precisely meant that if the cult of these individuals had existed one hundred years before the announcement of the decree, which was published in 1534 , and had existed in perpetuity since then, it could be respected within certain limits, and respect for individuals was also allowed who were traditionally part of the calendars of saints.

During the procedure of beatification and saint initiation, whether the candidate was formerly associated with a cult literally up to the beginning of the process which was approved by the Holy See had to be examined. If not (processus super non cultu), the procedure followed the restriction, but if so (processus super cultu), the congregation of the ritual had to examine since when the cult had existed, and whether it could it be called continuous. Despite this, news of saintliness (fama sanctitatis) obviously meant the beginning of beatification and canonization procedures: the Holy See examined what believers' opinions were about individuals' saintliness and the respect for the deceased; how permanent manifestations of the permitted cult were; and how persistently the latter claimed church approval for the respected deceased. ${ }^{14}$

As Peter Burke pointed out, these increasingly strict changes still did not mean that cults associated with people without canonization but respected as saints disappeared from public consciousness. ${ }^{15}$ Bohuslav Balbín, in the fourth volume of the Miscellanea historia regni Bohemiae series that was published in Bohemia Sancta in Prague in 1682, for example, dedicated a separate chapter to those people's biographies whose cult was not officially approved by the Holy See, but had been known among the Czechs from time immemorial; what is more, also those who had died in saintliness, but for whom even a local cult had not evolved. ${ }^{16}$ The cults associated with some individuals who had passed away while considered saints was so deeply embedded in public consciousness that even the centralized power of the church could not diminish it. Saint John of Nepomuk's public cult before his official ecclesiastic recognition was a typical example of this phenomenon. However, Balbín was not satisfied with collecting stories from earlier sources for biographies, and reported about individual and community devotional features and material relics.

13 Kubin, Kult des seeligen Hroznata, 43. Sidler, Heiligkeit aushandeln, 55-6.

14 Sidler, Heiligkeit aushandeln, 54-5.

15 Burke, "How to be a Counter-Reformation saint," 51. Copeland, "Saints, Devotions," 260-69.

16 Kovács Eszter, "Forgách Miklósné” 66-75, particulary: 67-9. Kovács, Cseh-magyar jezsuita kapcsolatok, 132. 
The most important novelty of Balbín's Saint John biographies was that they laid the ground for the recognition of a cult by the church through proving the right of a cult on the basis of Pope Urban VIII's restrictions.

In reviewing Saint John's early biographies, their obvious stratification can be noticed: they were completed throughout the centuries with portions of text that are cardinal points of early modern biography (and veneration as well). One, if not the most important element of these involved the keeping of the secrets of the confessional: Thomas Ebendorfer von Haselbach (1388-1464), an Austrian historian, was the first to write in Liber Augustalis (from 1433) that the reason for the conflict between Wenceslaus and Saint John of Nepomuk was that the priest had not told the sovereign what the queen had confessed to him. ${ }^{17}$ Another important part of early modern biographies were the descriptions of his penitentiary miraclesaccording to the tradition, those who doubted the saintliness of Saint John or deliberately stepped on his grave would suffer great shame the same day. In 1541, Václav Hájek z Libočan (1499-1553) first wrote about the existence of penitentiary miracles related to the saint's grave in his book Kronika Česká from $1541 .{ }^{18} \mathrm{He}$ first came up with the idea that two people had lived at the same time with a similar name: one of them had entered into confrontation with the sovereign about church policy, while the other-who was respected as a saint-had become a martyr associated with confessional secrets because of his conflict with Wenceslaus. ${ }^{19}$ This duality of Hájek's appears in the chronicle Historia regni Bohemiae of Jan Dubravius (14861553), Bishop of Olmütz, which was finished in 1552. Dubravius, on the basis of Hájek, also wrote about the penitentiary miracles related to the martyr: punishment for stepping on a grave was expanded with punishment for those who doubted the saintly existence of the confessor. ${ }^{20}$ The description of the martyr's grave and the manifestation of his material cult are emphasized by the author, even though the Holy See officially had not approved the martyr's cult: this content first appeared in Jan Tanner's Vir apostolicus seu vita et virtutes R. P. Alberti Chanowsky, published in $1660 .{ }^{21}$ Georgius Plachý (1586 k.-1655), a Jesuit monk with the working alias of Ferus, wrote Fama posthuma S. Joannis Nepomuceni, which was published in 1641 in Prague and reported about the spread of the martyr's cult, which was not only limited to Prague, but demonstrated that pilgrimages in Saint John's birth town, Nepomuk, were also significant in the middle of the seventeenth century. ${ }^{22}$

17 Herzogenberg and Paleczek, Johannes von Nepomuk, 113-114.

18 Herzogenberg and Paleczek, Johannes von Nepomuk, 114.

19 Kovács, Cseh-magyar jezsuita összefüggések, 189.

20 Reimann, "Johann von Nepomuk," 227.

21 Tanner, Vir apostolicus seu vita et, 14-20.

22 Fama Posthuma Ioannis Nepomuceni. 
The first critical biography was written by Jan Ignác Dlauhoweský (16381701) - who was the priest of the Týn church in Prague from 1667, and from 1679 vice bishop in Prague-with the title Proto-Historicus vitae S. Joannis Nepomuceni in $1668 .{ }^{23}$ This manuscript went into the capitular archives after the author's death, finally to be found by Jan Tomáš Vojtěch Berghauer, who published it in the second volume of his Protomartyr poenitentiae ejusque sigilli custos semper fidelis Divus Joannes Nepomucenus's second edition in $1761 .{ }^{24}$ The biography written by Dlauhoweský is not articulated into chapters but can thematically be clearly divided into biographical and cult sections. The author wrote about Saint John's birth, family, school, priestly career, personality, torture, martyrdom, and miracles as well. $\mathrm{He}$ recalled in the same elaboration the tangible memories and phenomena associated with the devotion, the martyr's patronage, the destruction of his grave by Calvinists, and also penitentiary miracles.

This sequence adumbrates the structure and content of Bohuslav Balbín's Saint John of Nepomuk biographies; the Jesuit hagiographer drew on this manuscript, sometimes in terms of content, but in some cases through obvious duplication.

Bohuslav Balbín wrote three different biographies about the martyr. ${ }^{25}$ The first printed biography was published in 1680 in Antwerp in the third volume of the month of May's Acta Sanctorum. ${ }^{26}$ The volume in which the chapter De B. Ioanne Nepomuceno Ecclesiae Metropol. Pragensis S. Viti Canonico Presb. Martyre Pragae et Nepomuci in Bohemia was attached was associated with 16 May, and discussed Saint John's life and cult, being edited by Gottfried Henschen, Daniel von Papenbroeck, and Konrad Janninck. The fact that Saint John's biography had its own place in an opus made for an international audience counted significantly in the spread of his cult.

Balbín listed the sources of the biography in the editor's comments preceding the biography, mentioning Hájek, Dubravius, Plachý, and the name of Jan Pešina z Čechodoru (1629-1680), a historian and also the name of the titular bishop of Smederevo, but he also emphasized that he had drawn on most of Jan Ignác Dlauhoweskýs biography, which manuscript he had personally studied. ${ }^{27}$ Using these sources, Balbín had edited a hand-written biography of the martyr by 1671, of

23 Reimann, Johann von Nepomuk, 237-46.; Herzogenberg and Paleczek, Johannes von Nepomuk, 115.

24 According to Berghauer it has been published in Prague in 1680 with the title Compendium Vitae S. Joannis Nepomuceni; I haven't found it. Berghauer, Protomartyr poenitentiae, 43-9, and 69-71.

25 See also: Kučera and Rak, Bohuslav Balbín; Tichás, "Einleitung zur tschechischen Auswahl”; Pokorná and Svatoš, Bohuslav Balbín; Szörényi, "Balbinus és a magyarok."

26 Balbín, "De B. Ioanne Nepomuceno," 667-80.

27 Balbín, "De B. Ioanne Nepomuceno," 667. 
which longer sections were quoted by Tomáš Jan Pešina z Čechorodu (1629-1680) in Phosphorus septicornis from $1673,{ }^{28}$ while its full length was published by Berghauer in $1761 .^{29}$ Balbín transferred the text of this manuscript into Acta Sanctorum and changed the structure in order to act upon Acta Sanctorum's general system of content. After the author's comments and Prologus, the text is divided into four chapters; the first two lay down the biography, the third notes the features of the martyr's cult, and the last one details the miracles that took place by his grave.

Balbín's grandiose almanac Miscellanea historia regni Bohemiae was published in 1679, volume by volume; the fourth volume with Saint John's new biography, Bohemia Sancta, was published in Prague in $1682 .{ }^{30}$ In Acta Sanctorum, reflecting the structural features of medieval legend literature, biographies are included according to anni circulus. In Bohemia Sancta, Balbín had ruled out use of this structural tradition and in grouping the different types of saints preferred thematic structuring. Chapter LIX of Bohemia Sancta includes the aforementioned biography with the title Vita Sancti Joannis Nepomuceni; ${ }^{31}$ here, there are seven chapters after the Prologus, of which the first five are about his life and death; the sixth about his cult; and the last about the miracles that happened at his grave.

In the latter, Balbín skipped the use of numbered subsections, like in Acta Sanctorum, but the page-setting clearly indicates the existence of these smaller text fragments. Compared with Acta Sanctorum, several smaller and some bigger changes can be noted between the two texts: most of these are minor changes included to promote interpretation or adjust the tone; others are shortenings of certain parts; the most important example of the latter concerns whether two people had lived with the same name at the same time, and how this was dealt with. ${ }^{32}$ This duality does not appear in Bohemia Sancta in the context it does in Acta Sanctorum: Balbín changed the text so that in seemingly inextricably contentious cases the chosen excellent judge may have been Saint John of Nepomuk in the Bohemia Sancta biography. The possibility of this duality can be read about at the end of the manuscript of Balbín's biography's from $1671,{ }^{33}$ and it also appears after the prayer that closes the Bohemia Sancta biography, ${ }^{34}$ in both cases with the title Ad vitam B. Joannis Nepomuceni, in which Balbín indicates this anomaly by referring to Dubravius (however, the latter biography writers did not adopt this content, but only the main text from Bohemia

\footnotetext{
28 Pešina z Čechodoru, Phosphorus septicornis, 650-52.

29 Berghauer, Protomartyr poenitentiae, 52-66.

30 Balbín, "Vita Sancti Joannis Nepomuceni."

31 Balbín, "Vita Sancti Joannis Nepomuceni," 94-113.

32 Kis, Nepomuki Szent János, 70-3.

33 Berghauer, Protomartyr poenitentiae, 66.

34 Balbín, "Vita Sancti Joannis Nepomuceni," 113.
} 
Sancta). This minor change was enough that in most later biographies there are signs of uncertainty concerning whether there was one martyr or if two people with similar names had entered into conflict with the king for different reasons.

As I have mentioned, Balbín's hand-written biography from 1671 was quoted by Pešina and Berghauer, in the latter at full length. ${ }^{35}$ Comparison of these texts with the biographies found in Acta Sanctorum and Bohemia Sancta proves that the very first biography's formal and content-based features from 1671 unequivocally reappear in Bohemia Sancta, presumably because here the writer was not taken with Gottfried Henschen's strict structural criteria, unlike in Acta Sanctorum. It can also be noticed that Balbín changed some details in the 1671 text for the Bohemia Sancta saint biography, and transposed parts from the version in Acta Sanctorum. ${ }^{36}$ This is interesting, because it can explain the kind of content-based and stylistic fragmentation of these early biographies, and especially their cult chapters: both the text in the Bohemia Sancta's (which was a duplex compilation within its author's life work), Acta Sanctorum's texts became the basis of the later biographies, so these anomalies became legacies of the latter texts, as well (such as the martyr's patronage, some penitentiary miracles, and the tangible memories of his devotion, which were mentioned in some measure in quite a few chapters).

Before canonization, but also in the following period, Bohuslav Balbín had far the greatest impact on Saint John biographies; without exception, even via multiple transfers in Acta Sanctorum or Bohemia Sancta authors leant on the text versions he had written (in some cases the later authors wrote the biographies by completing or updating the latter). The most important novelties of the martyr's biographies written by Balbín, in comparison with previous biographies, was that they proved, with great emphasis, that the martyr's cult had existed continuously since his death; that it had been preserved in all sorts of texts and in pictorial form; that such manifestations were typical of contemporary communities, irrespective of country borders; and finally that this devotion had become increasingly intensive and was typical of all layers of society.

It can be read from Jan Tanner, and referring to him, from Pešina, that although the martyr was not canonized, people called him a saint and respected him as one. Dlauhoweský, and quoting and completing him Balbín, was the first to systematically prove with a compelling amount of data the timelessness and continuity of his cult.

The biography-related publications that were chronologically the closest to the decree of 1634 strictly followed the restrictions by Pope Urban VIII in connection with the cult of people who had died as saints but were not canonized. For example, Fama Posthuma did not contain a descriptions of miracles, except for three that

35 Pešina, Phosphorus septicornis, 650-52.

36 Kis, Nepomuki Szent János, 72-3. 
Balbín aimed to prove with critical quotes and sources. However, he noted that Saint John's Prague and Nepomuk cult was a well-documented fact in the middle of the seventeenth century, but the congregation was trying to keep it within limits.

Jan Tanner was the first to write about the fact that even though the Holy See had not approved the martyr's cult, Saint John was still at the center of national devotion. ${ }^{37}$ After this, Dlauhoweský recalled this phenomenon, but did not argue with the Vatican's standpoint, but only noted the cult's features. ${ }^{38}$

Tanner's above-mentioned one-sentence characterization became one of the most important axioms in the saint biographies, and was unfolded in part by Balbín, so that later texts related to Acta Sanctorum or Bohemia Sancta adopted it. It can be established that the sub-points or chapters following the description of Saint John's funeral try to prove the legality of his cult; in Acta Sanctorum this portion is contained in the third; in Bohemia Sancta in the sixth chapter. This chapter, according to Balbín's multiplanar text editing, is not only about how Saint John of Nepomuk was respected in the past, but also proved why the cult is legal, and why it does not exist in contradiction of the restrictions declared by Pope Urban VIII. Accordingly, the claim by Tanner became an axiom in Balbín's cult chapters; the phrasing culminates in point by point confirmation of the latter. The fact that it is not only a biographical point but a demonstration of cult - a kind of pleading - is obviously indicated by the strict rhetorical structure.

The first paragraph in the chapter begins with a topic sentence which sums up the underlying problem: although Saint John of Nepomuk cannot be respected using the official methods associated with canonization by the church (masses, chants, etc.), he is respected with all other means with which the nation can pay homage to the canonized. ${ }^{39}$

In the narratio, Balbín wrote down point by point the components of this unofficial but real cult. It is interesting that Pope Urban VIII's restrictions defined only one limitation on Balbín and his co-authors-that according to the rituals of the

37 "Quare populi in eum veneratio ita crevit, ut tamensi a S. sede Apostolica (cuius solius est de vera viri huius sanctitate sine periculo erroris decernere) nulla accesserit autoritas, tantaeque ab haeresi per duo secula intercurrerint in Boemia tenebrae, pro sancto tamen \& vero Martyre sit semper habitus cultu publico, \& appensis ad eius sepulchrum anathematis." Tanner, Vir apostolicus, 16.

38 Reimann, Johann von Nepomuk, 237-46.

39 "Non erit abs re forsitan, priusquam ad miracula B. Joannis percensenda veniamus, pauca quaedam de publico ejus apud nos cultu praemittere. Sciendum in primis est, etsi B. Joannis memoria nullo neque Sacrificio neque divino Officio honoretur in templis (quod sine sanctae Sedis Auctoritate fieri non solet) reliqua tamen omnia, quibus Divorum nomina consecrantur, ad sacrum ejus tumulum adhiberi." Balbín, De B. Ioanne Nepomuceno, 673. 
church, they comply with Rome's demands and do not respect the martyr. However, this did not take into account the devotion's other (centrally forbidden) manifestations: the fact that according to the former's descriptions the martyr was called a saint and blessed, a church and altar were devoted to his honor, pictures of him had been put up, his grave was decorated with votive items and candles, he was pictured with symbols of saintliness, like a nimbus, and his miracles had been published. It is rather clearly written down in the biographies that Saint John of Nepomuk had gained significant respect by the second half of the seventeenth century. The texts also report information that confirms the position that the martyr's local cult long preceded Pope Urban VIII's restrictions. For example, it undoubtedly refers to the martyr's early cult that his grave was surrounded by an iron rail so that believers did not step on it, and that in 1530 Wenzel Picentinus von Wolfenburg (c. 1470-1548), the dean of the Prague prebendal, created for him a title in Latin which was quoted by a number of biographies I reviewed. ${ }^{40}$ The grave was destroyed by the Calvinists in 1619 when they unhallowed Saint Vitus Cathedral, but by 1621 it had already been restored.

The authors mentioned numerous tangible devotional items around this grave: candles, lanterns, ex votos and different boards, all characteristic projections of national piety, but implying the demand for constant presence and demonstration of Catholic faith (demonstratio catholica). ${ }^{41}$ Of these, the hagiographers emphasized the candle holder donated by Habsburg Archduke Leopold Wilhelm (1614-1662), Ferdinand II's son, on which the martyr's gold-plated bronze statue could be seen together with Czech national saints. First Fama Posthuma reported about this in 1641, after the announcement of the martyr's epitaph in Czech, then in a Latin letter text, and finally it was entered into all of the following biographies. ${ }^{42}$

The biography writers, beginning with Tanner, also report about artwork that invoked the rooting of a cult in the upper levels of the church rather than a manifestation of popular devotion: this includes reference to two altars devoted to him in Saint Vitus Cathedral. According to the cited biographies, on the first medieval altar the martyr is located among Bohemia's patrons, holding a palm branch symbolizing martyrdom; above his head an aureole is shining; beneath his title can be read in old handwriting "Saint John of Nepomuk." The second altar was canonized in honor

40 Herzogenberg and Paleczek, Johannes von Nepomuk, 114.

41 Tüskés and Knapp, "A katakombaszentek tisztelete," 3. From the grave see Matsche, "Das Grabmal."

42 "Patroni Bohemiae positi sunt in Candelabro. S. Vitus, S. Adalbertus, S. Wenceslaus, S. Procopius, S. Sigismundus, S. Ludmilla, S. Joannes de Nepomuk. Agnus vero cum Vexillo in loco superiori." Fama posthuma 1641, i. m. Inscriptio Sepulchri Beati Joannis Nepomuceni, without page number. 
of the Visitation of Virgin Mary, Saint Lucia, Saint Otilia, Saint Clement Pope, and Saint John of Nepomuk by John III Bishop of Prague (Jan Lohelius, 1549-1622) on 16 July 1621 according to Caspar Arsenius's description. Dlauhoweský also noted that Arsenius's description was shown to him by Pešina. ${ }^{43}$

It is an excellent indicator of the spread of the cult not approved by the Holy See that the patronage of the saint underwent transformation, including when and how his protective role was broadened with specific elements, in some cases that only referred to him personally, but then narrowed down primarily to the more general assistance he provided from the second half of the eighteenth century. In the biographies that I have studied the formation of the martyr's patronage can clearly be seen, the theoretical culmination of which lasted from Balbín's biographies until the time of canonization-more precisely, as proof of this until the middle of the eighteenth century. These special forms of patronage started to become part of the local canon from the seventeenth century onwards; before this, he was referred to as the martyr of the confessional secret, or without any protective role as God's true saint and martyr. ${ }^{44}$ In Fama Posthuma, the martyr's patronage had broadened, as he was referred to by Ferus as a protector against plague, wars, slander, and the conservator of repute who helps with both material and spiritual damage. ${ }^{45} \mathrm{After}$ this point, in all the biographies I reviewed, it was emphasized by the authors that the martyr helped in the case of conserving repute and protecting from slander. Dlauhoweský was the first to broaden Saint John's protective role with new elements: beyond being the protector of repute, he could assist women in labor, saving from drowning and falling-sicknesses, noting the well-known local proverb of the time that those who fear shame should respect Saint John of Nepomuk. ${ }^{46}$

43 About the altar, see Herzogenberg and Paleczek, Johannes von Nepomuk, 115.

44 We have information about the manifestation of his cult after his death: Jan $\mathrm{z}$ Jenštejna (Johann von Jenstein, 1348-1400), archishop of Prague, called him a saint martyr in the year of his death in a report written to Pope Boniface IX (1389-1404); also, in around 1393, on a flysheet published by Štěpán von Kolín prebendary, he is presented as a victim, together with Canterbury Saint Thomas, who died protecting the true belief. These sources were partly collected by Dlauhoweský, but mostly by Balbín in the chapters proving the timelessness and continuity of cult; both of them cited Václav Hájek z Libočan, Kronika Česká from 1541, in which the author calls Saint John of Nepomuk “God's saint martyr.” Herzogenberg and Paleczek, Johannes von Nepomuk, 113-14.

45 Fama Posthuma, 1641, Oratio ad S. Ioannem Nepomucenum confessarium, without page number.

46 “...maxime qui in periculo amissionis famae \& nominis integritate versantur, ad Eundem mox confugiunt, ac se juvari ac protegi dicunt, aut si quocunque modo Nomen laesum aut diminutum scierunt, redintegratum \& restitutum brevi senserunt, unde axioma \& proverbium in Regno enatum est: qui times infamari, debes Joannem venerari. Foeminae in partu graviter laborantes, hydropici \& febricitantes dum ad Eum confugiunt, se alleviari dicunt" Berghauer, Protomartyr poenitentiae, 47. 
Saint John's patronage has an element which can first be read about in Fama Posthuma: in the middle of the seventeenth century, the martyr provided protection in battle. ${ }^{47}$ In Dlauhoweský, this protection only appears in an indirect way, as he noted at the end of the manuscript that soldiers and other camp followers respected the martyr. ${ }^{48}$ Although this form of patronage cannot be read in Balbín, and it may not have been common knowledge, how important the role of soldiers were in spreading the cult before early canonization should be examined.

Balbín also played the main role in the public embedding of the martyr's community role, as he made these special patronages part of the contemporary canon. In Acta Sanctorum, the author referred to him as the protector of repute, the patron against slander, who helps even when someone does not confess their sins (the latter is a new element compared to Dlauhoweský). ${ }^{49}$ Balbín took Dlauhoweský as his basis and mentioned further patronages which are presented in the saint's latter biographies as well, while the aspect of iconography became increasingly emphatic: the former included help with water hazards and for laboring mothers, and help against some diseases. ${ }^{50}$ Balbín broadened the patron-narrative of him as a protector of fair name and against slander, referring to Wolfgang Chanowsky de Longavilla, Saint Vitus Cathedral's prebendary's description. There was a manuscript in the cathedral in which Saint John of Nepomuk's miracles were listed, but according to Balbín this volume had been lost during the cathedral's ruination in 1619. In this volume, the following helping miracles were listed:

Scribit is, in illo miraculorum libro, B. Joannem Nepomucenum Thaumaturgum Bohemiae appellari: caecum ad ejus tumulum recepisse visum, alios praesentissimam opem sensisse, alios in vitae mortisque confinio stantes, quosdam etiam ad supplicia mortis Judicum sententiis damnatos, beati viri, quem invocabant, auxilio, mirabiliter evasisse mortem. ${ }^{51}$

47 Fama posthuma... 1641, i. m. Oratio ad S. Ioannem Nepomucenum confessarium, without page number.

48 "Milites \& Castrenses homines felicem in suis successum vident, dum se Beato Joanni Commendant." Berghauer, Protomartyr poenitentiae, 48.

49 "Praecipuus B. Joannes Nepomucenus Patronus \& Tutator eorum habetur, quibus infamiae periculum aliquod imminet, quique ne admissum scelus factumve emanet in publicum, pertimescunt: occurit enim mirabiliter periculis, \& factum abcondit. (...) Iis quoque fert opem B. Ioannes, qui exitiali verecundia crimina sua in sacro tribunali aperire reformidant: nam ad ejus tumulum supplicantes, audaciam quamdam ad proferenda omnia addi sibi senserunt, idque aperte Sacerdotibus sunt testari." Balbín, De B. Ioanne Nepomuceno, 676-677.

50 "Nostra memoria matres aliquot, ad partum gravissime laborantes; alii hydrope, alii febribus diuturnis crudelissime vexati, fusis ad B. Ioannem precibus, convaluere, ut anathemata hodierna testantur." Balbín, De B. Ioanne Nepomuceno, 677.

51 Balbín, De B. Ioanne Nepomuceno, 675. 
Of these, the sparing of the doomed can be understood from Saint John's role as a protector against slander, but recovery from illnesses, especially the miraculous recovery of the blind, are part of the mediaeval miracles that occurred at the martyr's grave. A story about a blind man's recovery appears in Dlauhoweskýs biography, attached to the end, without citation, but indicating that he had read it in an old manuscript from Chanowsky, ${ }^{52}$ thus Balbín really was working from Dlauhoweskýs manuscripts in this case as well.

The textual part, again first mentioned by Dlauhowesky, invokes the traditions of miracle-literature that Balbín had adopted, ${ }^{53}$ especially the naive rituals of unfolding cults at saints' graves ${ }^{54}$ : dust collected from the martyr's grave had apparently resulted in numerous miraculous recoveries. ${ }^{55}$ Although the parts of biographies referring to this were quite short, in terms of the perspective of tangible memories of a relic cult, the manifestation of devotion was present, with great emphasis throughout Europe; the fact that private amulets and reliquaries of community respect contained dust from the martyr's grave shows the belief in it as a remedy. ${ }^{56}$

Saint John of Nepomuk was mainly considered the patron saint of repute and protector against slander from the second half of the seventeenth century until the middle of the eighteenth century; Johanna von Herzogenberg ascribed this to the influence of the Jesuits. ${ }^{57} \mathrm{I}$ doubt this statement by the researcher; the textual parts of the seventeenth-century biographies that I studied all imply that this patronage has spread spontaneously among believers, and the Jesuit (and other) authors only later reported and took it up.

The other significant form of Saint John's assistance was during plague and drought; patronage related to the latter was so important that on early modern plague monuments, especially those from the end of the seventeenth century until the middle of the eighteenth century, his statue sometimes appeared; this is also why he is listed among the early modern plague saints; the theoretical basis of this may also be connected to the biographies. The part about the pilgrimage to the Church of Pomuk can be read in Dlauhoweskýs manuscript, taken over by Balbín, ${ }^{58}$ which says that the martyr was effective assistance during the plague. Dlauhoweský noted

\footnotetext{
52 "In antiquo manuscripto repertum est, quod quidam caecus voto ad Beatum facto, visum receperint;" Berghauer, Protomartyr poenitentiae, 48-49.

53 Balbín, De B. Ioanne Nepomuceno, 677.

54 Balbín, De B. Ioanne Nepomuceno, 677.

55 "Multi solum pulvere ex ejus lapide sepulchrali modice collecto, ex pia veneratione, \& indubia fide, se adjutos in variis morbis ultro fassi sunt." Berghauer, Protomartyr poenitentiae, 47.

56 Szilárdfy, Magyar vonatkozások, 217; Klaniczay, “A csodatörténetek retorikája” 30-1.

57 Herzogenberg, “Zum Kult des heiligen," 30.

58 Berghauer, Protomartyr poenitentiae, 48.
} 
this more generally, without mentioning the year. ${ }^{59}$ Balbín appraised this as the great plague of 1649, which came together with droughts, when believers called for a procession for St. John. ${ }^{60}$

Saint John's cult had become deeply embedded in Czech society by the second half of the seventeenth century because of his patronages. One component of his cult is known and shows the truly privileged situation of the martyr from the sixteenth century onwards: the fact that he was listed among the Czech national saints. An early example of this is that Georg Barthold Pontanus von Braitenberg's Spirituale Regni Bohemiae jubilum volume from 1599 includes a biography about him and lists him as among the Czech national saints ${ }^{61}$ while in the Hymnorum Sacrorum, De Beatissima Virgina Maria, Et S. Patronis S.R. Bohoemiae. Libri tres volume, published in Prague in 1602, he is also set among the Czech national saints and a hymn is included about him. The fact that Saint John of Nepomuk is listed among Bohemia's patron saints comes up in a separate chapter in Fama Posthuma from $1641 .{ }^{62}$ In the biographies, in connection with Leopold's candle-holder, Tanner only mentioned that saint and martyr Saint John of Nepomuk appears on the decorational statuettes. ${ }^{63}$ Dlauhoweský wrote that Saint John was among the Czech patrons on the candle holder, but he also indicated his belonging among Czech patrons in another context: he briefly reported about the 180-year-old altar of Saint Vitus Cathedral, in which St. John can be seen alongside the Czech national saints; and he later refers to Chanowsky, who called him the miraculous saint of Bohemia. ${ }^{64}$

In Balbín, this narrative dominates the cult chapters of the biographies; it was the latter who developed Dlauhoweskýs more general entries with kind of a propagandistic purpose. Balbín's most expressive example appeared earlier as a marker of the Holy See's limited standpoint when he construed that those who arrive at the Saint Vitus Cathedral should pay their respects before Bohemia's patrons and automatically visit the martyr's grave as well. ${ }^{65}$

The trend to the expansion of Saint John's patronages confirmed the right of canonization. Furthermore, the texts mention such miracles with positive outcomes

59 “...nam peste ultima hic in Bohemia grassante, quicunque sibi Eum in Patronum elegerunt, ab ea liberati sunt." Berghauer, Protomartyr poenitentiae, 48.

60 "In peste, quae Bohemiam anno MDCXLIX pervagata gravissime afflixit, omnes qui sese Nepomuci B. Joanni commendarant, periculo sunt erepti.” Balbín, De B. Ioanne Nepomuceno, 674.

61 Herzogenberg and Paleczek, Johannes von Nepomuk, 115.

62 Fama Posthuma 1641, Sepultura ac depositio Beati Joannis Nepomuceni, without page number.

63 “...inter reliquorum Sanctorum statuas, etiam B. Joannem Nepomucenum." Vid. Tanner, Vir apostolicus, 16-7.

64 Berghauer, Protomartyr poenitentiae, 47.

65 Balbín, De B. Ioanne Nepomuceno, 673. 
that not only related to the patronages, but, independent of them, forecast the martyr's penitentiary miracles that ensured that disbelievers were punished with their opposite orientation. It can first be read in Dlauhoweský that when the martyr's grave was dug up, the canons found a coffer with which the deceased had given thanks for the last honors that had been given to him; ${ }^{66}$ this story was also adopted by Balbín. The observation of this important role in assistance appeared in biographies, which again may have fostered the spread of his cult: the latter included punishment for those who doubted his saintliness or showed disrespect at his grave.

Hájek and Dubravius reported in the sixteenth century that God does not leave unpunished those who would mock his saints. One of the most often cited penitentiary miracles involved Christophorus Sluska, palatine of Wenden (palatinus), who was on a mission with Radvila, a Lithuanian prince, to Rudolph II, and had been disrespectful at the grave. Because of this he was in great shame-this claim was published attached to the end of Fama Posthuma in $1641 .{ }^{67}$ We cannot read in Tanner about such significant later penitentiary miracles, and Dlauhoweský only included two examples of these from a statement from Dubravius, which say that it is shall not be left without consequence if someone doubts the martyr's saintliness. A skeptical woman who found the martyr's saint portrait twice, and the story of a monk who did not recover from his illness until he regretted that he had not believed in his saintliness, are gentle signs of penitentiary miracles that were written down by Balbín.

So the penitentiary miracles became dominant in Balbín's biographies; the basic message they conveyed was as important as proving the timelessness and continuity of his cult: Acta Sanctorum's biography's last (fourth) chapter mainly emphasizes the consequences of disrespect and doubt. ${ }^{68}$ The quoted story of Sluska the palatinus and that of Albert Chanowsky, first mentioned in Tanner's biography, were only about shame. Stories related to the Calvinists' church ravages-Baron Wenceslaus Wilhelmus de Raupowa who went mad because he had lost his son due to his disrespectfulness, or the English-born preceptor of Frederick V, who was obsessed with dishonoring the martyr's grave-were stories more than effective warnings. ${ }^{69}$ In these stories, the thief who breaks off Saint John's statue from the Leopold candle-holder gets fair justice,

66 Berghauer, Protomartyr poenitentiae, 46.

67 Fama posthuma... 1641. Dei Poena in impios and the last note without a title, both are without page numbers.

68 Balbín, De B. Ioanne Nepomuceno, 675-77.

69 This is not limited to contenporary written memories: Kašpar Bechteler's relief of around 1630 in the parvis of Saint Vitus Cathedral in Prague shows the ruination of the grave, and men are escorting the half-dead gravedigger out of the cathedral. This relief can be viewed as a penitentiary miracle as much as a historical report (it is kind of a "warning" to visitors). 
as does the girl whose skirt is blown up around her neck by the wind because of her disrespectfulness, as do the overweening noblewoman and the parish clerk who teases his mate at the grave. The number and elaboration of penitentiary miracles in Balbín exceeds by long odds those of rewarding miracles; the moral lesson of such biographies is that those who would disrespect the agreement between God and his saint will regret it. These miracles symbolize the heritage of medieval martyr stories, with one important difference: punishment in these cases is not afterlife perdition, but shame in this life, or in more serious cases, madness.

Miracles are in all cases essential parts of saint stories: when they are connected to the person in life, and also when the latter is witnessed and praised by the Creator after his death; a miracle is kind of a sign (signum), which shows that God is working in the saint. ${ }^{70}$ The fact that miracles happen in relation to saints shows the presence of God and his chosen one, the dominance of which cannot be emphasized enough after the headway made by the Reformation. Balbín's description, which focuses on penitentiary miracles, does more than this: in the previous chapter he demonstrates the timelessness and continuity of cult, and in the last, he discusses what happens if someone doubts saintliness, or what can attract even more serious consequencesnamely, if a person is disrespectful at the grave or with his person.

The spread of Saint John's cult was promoted by the authors who assigned him a character, face, and thus a kind of visibility with their text. The biographies report about the martyr's representation and its features. The descriptions in the biographies were started by Dlauhoweský, and Balbín completed them in the usual way. I summarize the changes between the texts in Table 1 .

As we can see, Balbín, when compared to Dlauhoweský, paid great attention to reporting about Saint John's visualization(s). Their common characteristic is that the martyr has a nimbus in all of them; this is Balbín's most important statement in connection with the saint's iconography, and the reason for its emphasis is unambiguously polemization with Pope Urban VIII's regulations: those who were not canonized were not allowed to be pictured with the visible symbols of saintliness, and they could not be called "saint" or "blessed." Perhaps it was for this reason that Balbín put down in the biography that several candles and votive items, and the martyr's picture with rays had been placed next to the grave; because of the papal prohibition, none of this should normally have been done. Balbín explained these phenomena in his own words: the fact that he is called saint or blessed in these pictures and that there is heavenly light around his head is because of the martyr, not the weakness of human soul..$^{71}$

\footnotetext{
70 Sághy, "Bevezetés," 25-6.

71 Balbín, De B. Ioanne Nepomuceno, 673-74.
} 
Table 1 Differences between Dlauhoweský's and Balbín's texts regarding the martyr's representation

\begin{tabular}{|c|c|c|}
\hline & Berghauer, 1761, i. m. & Balbín 1680. i. m. \\
\hline $\begin{array}{l}\text { visualization in the form } \\
\text { of a picture hung by his } \\
\text { grave }\end{array}$ & $(-)$ & $\begin{array}{l}\text { Pendent hinc inde cerea lumina, \& } \\
\text { varia anathemata; tum B. Joannis } \\
\text { imago radiata (p. } 673 \text { ) }\end{array}$ \\
\hline $\begin{array}{l}\text { visualization in saint } \\
\text { portraits }\end{array}$ & $(-)$ & $\begin{array}{l}\text { Jam vero imagines B. Joannis aeri } \\
\text { incisae habentur in manibus: in his } \\
\text { \& Beati titulus Joanni apponitur, \& } \\
\text { capitis apex ardens caelesti lumine } \\
\text { ac circumfulis radiis spectatur ( } \mathrm{p} \text {. } \\
674 \text { ) }\end{array}$ \\
\hline $\begin{array}{l}\text { visualization on the altar, } \\
\text { as common with Czech } \\
\text { patron saints }\end{array}$ & $\begin{array}{l}\text { B. Joannes Nepomucenus cum } \\
\text { palma, \& circum caput radio } \\
\text { depictus \& sanctus nominatus } \\
\text { invenitur (p. 47) }\end{array}$ & $\begin{array}{l}\text { Has ergo inter imagines Divorum } \\
\text { Joannes Nepomucenus palmam } \\
\text { sustinet manibus, radiato capite } \\
\text { undiquae illustris (p. } 674 \text { ) }\end{array}$ \\
\hline $\begin{array}{l}\text { visualization on the altar } \\
\text { of Pomuk Church }\end{array}$ & $(-)$ & $\begin{array}{l}\text { In summa novi hujusce templi } \\
\text { ara B. Joannis imago radiata } \\
\text { conspicitur (p. 674) }\end{array}$ \\
\hline $\begin{array}{l}\text { visualization in the saint } \\
\text { portraits, - the woman was } \\
\text { doubtful of the martyr's } \\
\text { saintliness }\end{array}$ & $\begin{array}{l}\text { imaginem mirae pulchritudinis } \\
\text { sancti Joannis in libello reperit } \\
\text { cum radio in habitu Canonicali, } \\
\text { \& inscriptione: Sanctus Joannes } \\
\text { Nepomucenus Martyr (p. 47) }\end{array}$ & $\begin{array}{l}\text { reperit in libello precum Beati } \\
\text { effigiem capite radiato in habitu } \\
\text { Canonicorum venustissimam (p. } \\
677 \text { ) }\end{array}$ \\
\hline
\end{tabular}

We have information about the spread of Saint John's cult outside Prague from the middle of the seventeenth century, as in the martyr's birth town of Pomuk (today's Nepomuk) there were annual pilgrimages, and through the Sternberg family's donation a church was built between 1639 and 1660. The seventeenth-century spread beyond town boundaries and flourishing of the future saint's cult came with a major rise in the number of pilgrims..$^{72}$ Fama Posthuma reported about the Sternberg church in 1641, and Dlauhoweský also paid tribute to it. The latter wrote that there had been a small chapel before on the site, and that altarpiece of the martyr in the church was blessed with Gregorian water with the permission of archbishop Harrach. ${ }^{73} \mathrm{He}$ also wrote about how inventive were the rites of the mass held

72 The church that stands today was rebuilt according to Kilian Ignaz Dietzenhofer's plans between 1734-1738 due to the expanding number of pilgrims.

73 "Cum antea Sacellum vetustum stetisset (in the related footnote: Nullum setit ibi vetustum Sacellum, sed primo primum Sacellum ibi aedificavit Franciscus Comes de Sternberg). Major Ara ejus imagine insignis visitur ex indultu Eminentissimi Cardinalis ab Harrach Aschi-Episcopi Pragensis aqua Gregoriana benedictum." Berghauer, Protomartyr poenitentiae, 48. Aqua Gregoriana: this is what the water used at church- and altar consecrations was called until the II Vatican council. However, it is interesting that Dlauhoweský writes "benedictum" and not "consecration,"-it would be worth examining in terms of canon law whether there is a difference. 
on the saint's day of death, designed both accordingly to pilgrims' demands and the Holy See's regulations (mass was held in honor of the Trinity, but the sermon was about Saint John of Nepomuk). ${ }^{74}$

This short report was again transformed by Balbín: he wrote in Acta Sanctorum that after the death of the martyr the locals had built a chapel. ${ }^{75}$ Balbín emphasized in connection with the church built with the donation of Franciscus von Sternberg that, in honor of the martyr, ${ }^{76}$ it had been sanctified with the permission of Ernst Adalbert von Harrach (1598-1667), archbishop of Prague. ${ }^{77}$ This can be considered Balbín's artifice, as Dlauhoweský had not referred to this. Balbín noted that the mass was held in honor of the Trinity, but the sermon was about Saint John of Nepomuk. ${ }^{78}$ According to Balbín's description, there was an altar consecrated in honor of Saint John of Nepomuk which had been painted by Karel Škréta; an aureole can be seen in this around the martyr's head. ${ }^{79}$ In the church — similarly to in Saint Vitus' Cathedralboth individual and communal tangible memories of piety appear in great numbers according to Balbín's description; these ex votos prove the timelessness of the cult. ${ }^{80}$ And not only did individual pilgrims come to the Pomuk church - the text tells that peregrination was organized by local parsons since time immemorial. ${ }^{81}$

This story is only partially true: with the donation of the Sternberg family in the middle of the seventeenth century a church was built in the town-Fama Posthuma reports about this in 1741. But in fact it was sanctified in honor of Saint

74 "Habent \& singulis annis jam ex immemorabili tempore Beati memoriam, cum affluxu \& multitudine populi, \& convocatione Cleri vicini devote celebrant, licet Sacrum de Sanctissima Trinitate tantum fiat, Concio tamen est de Joannis virtutibus eximiis." Berghauer, Protomartyr poenitentiae, 48 .

75 “...oppidanorum pietas sacellum B. Joannis honoris tatim ab ejus morte exstruxit” Balbín, De B. Ioanne Nepomuceno, 674.

76 "B. Ioannis Nepomucensis honori magnis sumptibus exstruxit" Balbín, De B. Ioanne Nepomuceno, 674 .

77 With his permission, but not with his participation: maybe it is not accidental that Balbín's opinion was that the archbishop did not take part in the ceremony due to an illness; consequently, an objective reason: "cum ipsemet per invaletudinem adesse \& consecrare non posset." ld. Balbín, De B. Ioanne Nepomuceno, 674.

78 "Sacra de B. Joanne non leguntur quidem, sed de sanctissima Trinitate: Concio tamen ad Populum de B. Joannis virtutibus habetur." Balbín, De B. Ioanne Nepomuceno, 674.

79 "In summa novi hujusce templi ara B. Joannis imago radiata conspicitur" Balbín, De B. Ioanne Nepomuceno, 674.

80 "Appensa visuntur ad ejus aram anathemata plurima, satenturque diversi ejus se meritis varia beneficia caelitus impetrasse." Balbín, De B. Ioanne Nepomuceno, 674.

81 "Aditur B. Joannis ecclesia multis supplicationibus: parochi a multis passuum millibus ad certam diem ab operibus vacuam, Dominicis inter Pascha \& Pentecosten, populum adducunt: idque agitur a tempore immemorabili." Balbín, De B. Ioanne Nepomuceno, 674. 
John the Baptist, not Saint John of Nepomuk, ${ }^{82}$ but coevals knew about this. Georgius Crugerius's (a Jesuit father; 1608-1671) Majales Triumphi Romano-Catholicae celebrandi fortitudinis celebrandi etiam hodie a Posteris Plsnensium, published in 1659, emphasizes that Sternberg's church was consecrated in honor of Saint John the Baptist and not the martyr, with the permission of Archbishop Harrach, according to the Holy See's restrictions on the cult of individuals who are not canonized yet. ${ }^{83}$

Dlauhoweský, and from him Balbín, also noted that shortly after the martyr's death the locals wanted to build a chapel at the place of his birth, as miraculously no one could have a good night sleep until it was built. This information was supplied, with notes, by Berghauser, who published Dlauhoweskýs manuscript, and who stated that in this case the author was mistaken, as it was confirmed during the canonization process that there had been no chapel before the Sternberg building. ${ }^{84}$ This was according to Eduard Reimann Balbín, who according to Georgius Crugerius's report must have known the correct data as he had visited the place before writing his biography. ${ }^{85}$ Why Balbín did not write the truth in his biographies (according to Reimann) is that he had to prove the martyr's timeless and continuous cult-without this, according to Pope Urban VIII's restrictions connected to the cult of saints, the legality of the Pomuk cult could have been questioned.

If the thesis that Balbín (in chapter six) was actually pleading against Pope Urban VIII's restrictions on the cult of saints is relevant, then the finisher has to be the reflections in the introduction that contain conclusions that support the truth of Balbín. After the above-listed evidence in the peroratio, Balbín indeed turns to the axiom of the introduction and makes a note referring to Gottfried Henschen: he states that in the case of those who die in saintliness and whose cult dates back more than a hundred years, Pope Urban VIII had not clearly prohibited the informal continuation of their cult.

Gottfried Henschen (1601-1681), a Jesuit hagiographer and student of Jan Bolland's, took part in the work of Acta Sanctorum from 1735, as Bolland charged him with preparing the hagiographies for February. ${ }^{86} \mathrm{He}$ took his task seriously and

82 Reimann, Johann von Nepomuk, 238.; Matsche, "Die Darstellungen des Johannes von Nepomuk," 41.

83 "Sed titulus non Joannis Nepomuceni, verum Joannis Baptistae ex indulto Eminentissimi Cardinalis ac Archiepiscopi interim Novitiae Ecclesiae consessus est; quia Romanus Pontifex ritibus solennibus negotio legitime necdum examinatio causam Martyrii nondum determinavit, licet ei coelo tot, ut diximus prodigia faveant imo humanam negligentiam per tot centurias annorum, quasi condemnent." Berghauer, Protomartyr poenitentiae, 50-1.

84 Berghauer, Protomartyr poenitentiae, 49.

85 Reimann, Johann von Nepomuk, 238.

86 Delehaye, Work of the Bollandists, 28-30. 
successfully showed his master his first biography, which was a work on Saint Vedas's and Saint Amand's life and cult, in which he wrote in a more rigid way, navigating philological, historical, and geographical problems with a critical perspective, ${ }^{87}$ as the formal form of hagiographies in Acta Sanctorum were written on the basis of the new method from then onwards. Henschen was a contemporary of Urban VIII who had made up the restrictions in connection with the cult of saints, and who responded to the prescriptions of Coelestis Hierusalem (the regulations appeared simultaneously with the work of the Bollandists and had an effect on the Church!) with his work Venerationi Divorum, from which Balbín literally cited the right of the martyr's cult. ${ }^{88}$ Henschen-according to the text in Venerationi Divorum-argued that Pope Urban VIII did not mind the public cult of people who had died in saintliness, if the cult had persisted continuously from time immemorial; both the miracles at the martyr's grave and public respect prove this. First, Henschen was not cited by Balbín in Acta Sanctorum, as in the 1671 hand-written biography he finished chapter six with this content; ${ }^{89}$ and it appears in Bohemia Sancta just the same.

As I have shown, Saint John's early modern biographies (since Dlauhoweský and especially those of Balbín) contain unusual stratification that made an example of all individual and communal manifestations of the martyr's cult. It can also be stated that Balbín's biographies are the results of compilation, in the way that his work became the main source of later texts. At first reading, it might seem that Balbín had only transposed Tanner's reference about the timelessness and continuity of cults (which did not conflict with Pope Urban VIII's restrictive orders), and also transferred the content of Dlauhoweskýs manuscript, completing it with a few more miraculous stories, thereby creating a biography with not too many original thoughts by the author. This amount of compilation is not a value judgement in itself, as during the seventeenth-eighteenth centuries such transposition was a fully accepted, almost common practice of authors.

Balbín's texts were more than simple compilations, as by restructuring, patching, and completing the texts he created biographies that, from the perspective of different layers of meaning, became far more effective than the texts from which he

87 De S. Vedasto Episcopo Atrebatensi in Belgica, De S. Amando Episc. Trajectensi elnone sive Amandopoli in Belgico, in Acta Sanctorum, Februarius Tomus I. (Antwerpen, 1558), 790-912.

"De ejusmodi vetusta religione et cultu Beatorum antiquo, optime dixit vir eruditissimus, et in gestis Divorum describendis et illustrandis diligentissimus, rerumque istarum peritissimus, Godefridus Henschenius: Venerationi Divorum, inquit, à tempore memoriam unius saeculi excedente, Urbanus VIII, Pont. Max. nihil voluit derogatum, quo minus perpetua deinceps esset. Jam B. Ioannis cultu ab antiquitate probato, ad miracula, ad ejus sacrum tumulum patrata, faciamus gradum: simul illud patebit, quam merito tantus eidem à populo cultus habeatur." Balbín, De B. Ioanne Nepomuceno, 674. 
had worked. Balbín reacted to the increasingly emphatic demand in Czech society for Saint John's canonization; he shaped the events with his biographies in a way that his intellectual presence is obviously felt in later Czech hagiographies, in the success of St John's canonization, and in the spread of Saint John's cult.

\section{Sources}

Fama Posthuma Ioannis Nepomuceni, Pragae: Typis Academicis [1641].

Berghauer, Jan Tomáš Vojtěch. Protomartyr poenitentiae ejusque sigilli custos semper fidelis Divus Joannes Nepomucenus, Tomo Secundo, Augustae Vindelicorum, 1761.

Balbín, Bohuslav. "De B. Ioanne Nepomuceno.” In Acta Sanctorum, Maii, Tomus III, edited by Gottfried Henschen, Daniel von Papenbroeck, Konrad von Janninck, 667-680. Antwerpen, 1680.

Balbín, Bohuslav. "Vita Sancti Joannis Nepomuceni." In Miscellanea historica regni Bohemiae decadis I. liber IV. hagiographicus, seu Bohemia sancta, edited by Bohuslav Balbín, 94-113. Pragae: typis Georgij Czernoch, 1682.

Pešina z Čechodoru, Tomáš. Phosphorus septicornis, stella alias matutina, Pragae: Typis Joannis Arnolti de Dobroslavina, 1673.

Tanner, Jan. Vir apostolicus seu vita et virtutes R. P. Alberti Chanowsky, Coloniae Agrippinae: Sumptibus Nicolai Hosino, 1660.

\section{Bibliography}

Aigrain, René. L'hagiographie: Ses sources, Ses méthodes, Son historie. Bruxelles: Société des Bollandistes, 2000.

Burke, Peter. "How to be a Counter-Reformation saint." In The Historical Anthropology of Early Modern Italy. Essays on perception and communication, edited by Peter Burke, 48-62. and 130-142. Cambridge University Press, Cambridge, 1987.

Copeland, Clare. "Saints, Devotions and Canonisation in Early Modern Italy" History Compass 10, no 3 (2012): 260-69. doi.org/10.1111/j.1478-0542.2012.00834.x

Delehaye, Hippolyte. The Work of the Bollandists Through Three Centuries, 16151915, Princeton: Princeton University Press, 1922.

Denzinger, Heinrich and Peter Hünermann. Hitvallások és az Egyház Tanitóhivatalának megnyilatkozásai, translated by Fila, Béla, and László Jug, edited by Romhányi, Beatrix, and Gábor Sarbak. Bátonyterenye: Örökmécs, Budapest: Szent István Társulat, 2004.

Denzinger, Heinrich and Peter Hünermann. Das Trienter Konzil und seine Rezeption im Ungarn des 16. und 17. Jahrhunderts. Studien und Texte 171, edited by Fata, 
Márta, András Forgó, and Gabriele Haug-Moritz, Anton Schindling. Münster: Aschendorff, 2019.

Ditchfield, Simon. "How Not to Be a Counter-Reformation Saint. The Attempted Canonization of Pope Gregory X, 1622-45," Papers of the British School at Rome 60, (1992): 372-422. doi.org/10.1017/S0068246200009879

Ditchfield, Simon. "Thinking with Saints. Sanctity and Society in the Early Modern World" Critical Inquiry 35, (2009): 552-84. doi.org/10.1086/598809

Ditchfield, Simon. "Tridentine Worship and the Cult of Saints" In The Cambridge History of Christianity. Vol. 6. Reform and Expansion 1500-1660, edited by R. Po-Chia Hsia, 201-24. Cambridge: Cambridge University Press, 2007. doi.org/ 10.1017/CHOL9780521811620.013

Dufflin, Jacalyn. Medical Miracles. Doctors, Saints, and Healing in the Modern World. Oxford: Oxford University Press, 2008.

Eire, Carlos M. N. War against the Idols. The Reformation of Worship from Erasmus to Calvin. Cambridge: Cambridge University Press, 1989.

Gregory, Brad S. Salvation at Stake. Christian Martyrdom in Early Modern Europe. Harvard Historical Studies 134. Cambridge, MA: Harvard University Press, 1999

Hecht, Christian. Katholische Bildertheologie im Zeitalter von Gegenreformation und Barock. Studien zu Traktaten von Johannes Molanus, Gabriele Paleotti und anderen Autoren. Berlin: Gebr. Mann, 1994.

Herzogenberg, Johanna von. "Zum Kult des heiligen Johannes von Nepomuk” In Johannes von Nepomuk, edited by Franz Matsche, 25-34. Passau, 1971.

Herzogenberg, Johanna von and Raimund Paleczek. „Johannes von Nepomuk” In Die Landespatrone der böhmischen Länder. Geschichte, Verehrung, Gegenwart, edited by Stefan Samerski, 109-122. Paderborn-Munich-Vienna-Zürich: Ferdinand Schöningh, 2009. doi.org/10.30965/9783657766796_010

Johns, Christopher M. S. "Sanctity and social utility. Making Saints int he Era of Catholic Enlightenment" In The visual culture of catholic enlightenment, edited by Christopher M. S. Johns. Pennsylvania: The Pennsylvania State University Press, 2015.

Kapner, Gerhardt. Barocker Heiligenkult in Wien und seine Träger. Vienna: Verlag für Geschichte und Politik, 1978.

Kis, Tímea N. “'Kiben Isten abban az üdöben magát kiváltképpen jelenteni akarta’ Nepomuki Szent János tiszteletének meghonosítása Magyarországon” [Introducing of the cult of Saint John of Nepomuk in Hungary]. PhD Diss., Eötvös Loránd University, 2020. doi.org/10.15476/ELTE.2020.067

Klaniczay Gábor. "A csodatörténetek retorikája a szentté avatási perekben és a legendákban.” In Religió, retorika, nemzettudat régi irodalmunkban, edited by Bitskey, István and Szabolcs Oláh, 29-49. Bibliotheca Studiorum Litterarium 13. Debrecen: Kossuth Egyetemi Kiadó, 2004. 
Kovács Eszter. "Forgách Miklósné Bossányi Eszter életrajza Bohuslav Balbín Bohemia Sanctájában.” Magyar Sion Új Folyam 45, no 1 (2009): 66-75.

Kovács, Eszter. Iszlámismeret Csehországban a 16-17. század fordulóján [Islamic studies in the Czech Republic at the turn of the 16th and seventeenth centuries]. Budapest: Országos Széchényi Könyvtár - Pázmány Péter Katolikus Egyetem, 2017.

Kubin, Petr. "Der Kult des seligen Hroznata im Barock" In Transregionalität in Kultund Kultur. Bayern, Böhmen und Schlesien zur Zeit der Gegenreformation, edited by Marco Bogade, 35-58. Cologne-Weimar-Vienna: Böhlau Verlag, 2016. doi.org/ 10.7788/9783412502713-004

Kučera, Jan and Jiří Rak. Bohuslav Balbín, a jeho místo v české kultuře Vyšehrad, 1983.

Leone, Massime. Saints and Signs. A semiotic reading of conversion in early modern catholicism. Berlin-New York: de Gruyter, 2010. doi.org/10.1515/9783110229523

Louthan, Howard. Converting Bohemia. Force and Persuation in the Catholic Reformation. Cambridge: Cambridge University Press, 2009.

Louthan, Howard. "Tongues, Toes and Bones. Remembering Saints in Early Modern Bohemia." In Relics and Remains, , edited by Alexandra Walsham, 167-83. Past \& Present 206. Oxford: Oxford University Press, 2010. doi.org/10.1093/pastj/gtq017 Matsche, Franz. "Die Darstellungen des Johannes von Nepomuk in der barocken Kunst. Form, Inhalt und Bedeutung." In Johannes von Nepomuk, edited by Franz Matsche, 35-62. Passau: Passavia, 1971.

Matsche, Franz. "Das Grabmal des hl. Johannes von Nepomuk in Prager Veitsdom." Wallraf Richartz Jahrbuch 38, (1976): 92-122.

Pokorná, Zuzana and Martin Svatoš. Bohuslav Balbín und die Kultur seiner Zeit in Böhmen, Köln-Weimar-Vienna, 1993.

Reimann, Eduard. "Johann von Nepomuk nach der Sage und nach der Geschichte." Historische Zeitschrift 27, (1872): 225-81. doi.org/10.1524/hzhz.1872.27.jg.225

Sághy, Marianne. "Bevezetés: Szent Odó és a szeretet rendje.” In Salernói János, Szent Odó élete. Translated and edited by Sághy, Marianne, 10-34. Budapest: L'Harmattan, 2009.

Sallmann, Jean-Michel. Naples et ses Saints à l'âge baroque (1540-1750). Paris: PUF, 1994.

Samerski, Stefan. "Wie im Himmel, so auf Erden?" Selig- und Heiligsprechung in der Katolischen Kirche 1740 bis 1870. Stuttgart: Kohlhammer, 2002.

Sidler, Daniel. Heiligkeit aushandeln: Katholische Reform und lokale Glaubenspraxis in der Eidgenossenschaft (1560-1790). Frankfurt-New York: Campus Verlag, 2017.

Sieger, Marcus. Die Heiligsprechung. Geschichte und heutige Rechtslage. Würzburg: Echter, 1995.

Shore, Paul J. The Eagle and the Cross. Jesuits in Late Baroque Prague Saint Louis: Institute of Jesuit Sources, 2002. 
Shore, Paul J. Die Landespatrone der böhmischen Länder. Geschichte, Verehrung, Gegenwart, edited by Stefan Samerski. Paderborn-Munich-Vienna-Zürich: Ferdinand Schöningh, 2009.

Suire, Éric. La sainteté française de la Réforme catholique (XVI $-X V I I I^{e}$ siècle), d' après les textes hagiographiques et les procèse de canonisation. Pessac: Presses Universitaires de Bordeaux, 2001.

Szilárdfy Zoltán. "Magyar vonatkozások Nepomuki Szent János kultuszában és ikonográfíjában.” In Ikonográfia - Kultusztörténet, edited by Szilárdfy, Zoltán, 213-20. Budapest: Balassi Kiadó, 2003.

Szörényi, László. "Balbinus és a magyarok" In Philologica Hungarolatina. Tanulmányok a magyarországi neolatin irodalomról, edited by Szörényi László, 91-100. Budapest: Kortárs Kiadó, 2002.

Tichás, Zdeňka. "Einleitung zur tschechischen Auswahl aus Balbinus Miscellanea." In Krásy a bohatství české země, by Bohuslav Balbín, Zdeňka Tichá, and Helena Businská, 11-45. Praha: Panorama, 1986.

Tüskés, Gábor and Éva Knapp. "A katakombaszentek tisztelete. Fejezet a barokk kori szent- és ereklyekultusz történetéből.” Századok 128, no. 1 (1994): 3-31.

Tusor, Péter. „A magyar egyház és a Sacra Rituum Congregatio a katolikus reform korában (A kongregáció alapításától 1689-ig)," Magyar Egyháztörténeti Vázlatok 11, no. 1-2 (1999): 35-66.

Tusor Péter. A barokk pápaság (1600-1700). Budapest: Gondolat Kiadói Kör, 2004.

Veraja, Fabian. La Beatificazione. Storia, problemi, prospettive (Sussidi per lo studio delle Cause dei Santi 2). Roma: S. Congregazione per le Cause dei Santi, 1983

Vidal, Fernando. "Miracles, Science, and Testimony in Post-Tridentine Saint-Making," Science in Context 20, no. 3 (2007): 481-508. doi.org/10.1017/S0269889707001391

Waterworth, James. The Council of Trent. The canons and decrees of the sacred and oecumenical Council of Trent. London: Dolman, 1848.

Worchester, Thomas. "Saints as Cultural History," In Exploring Cultural History: Essays in Honour of Peter Burke, edited by Melissa Calaresu, Filippo de Vivo, and Jean-Paul Rubiés Ashgate: Aldershot, 2010, 191-206. 